\title{
Obituary
}

Mr. G. E. Collins

$\mathrm{T}$ HE melancholy accident on July 30 that deprived England of a soaring pilot of international reputation has also caused a serious loss to meteorology. Mr. G. E. Collins only began gliding in 1932, and with extreme rapidity acquired very great technical skill. But above all he had insight and imagination : he was always trying to increase, and to apply, our knowledge of air-currents. He was in close touch with some of the finest German pilots, and like them made use of cumulus clouds and 'fronts' to gain height that could be converted into horizontal travel. $\mathrm{He}$ learned from Wolf Hirth the method of soaring in a spiral in a 'thermal' (an up-current without a cloud to mark it) by the use of a variometer, steering in the direction in which the uplift was greatest; but he soon discovered a method of soaring in thermals without a variometer, using his body sensations and steering towards the wing which was the more strongly lifted. To-day probably a dozen British pilots can climb in thermals, but they owe much to Collins's peculiar gifts.

Collins was among the foremost to make use of the up-currents suggested by theory under the long lines of cloud that form parallel to the wind direction, realising their value for flights down-wind. Accordingly, in August 1934 he employed these 'cloudstreets' in a flight of 98 miles from Dunstable to Holkham Bay, still the British record : he reached the Norfolk coast at a height of 3,000 ft., and showed that it is only the dimensions of our island that impose the limit on cross-country flights.

In July last year, Collins extended ideas by providing a reply to the criticism that gliders can only sail down-wind. In a flight in a west-south-west wind, he passed over Watford and alighted at Hanworth, due south of it; his speed relative to the air was not only much faster than the wind, but its direction must have been within $45^{\circ}$ of straight into it. Now that tacking is possible, much can be done.

It had been hoped that Collins's skill might have been employed in carrying self-recording instruments round and through clouds in order to get much needed data procurable in no other way; may his fine example inspire others to take up this work.

G. T. W.

\section{Dr. Helen Chambers}

By the death of Dr. Helen Chambers on July 21, Great Britain has lost one of its most devoted workers in the cause and treatment of cancer. She received her medical education at the London School of Medicine for Women, took her M.B. with first-class honours in 1903, and was a gold medallist. At twenty-four years of age, she was appointed pathologist to the Royal Free Hospital, a post she held until 1915, when she resigned to take up a similar position at the Endell Street Military Hospital.
Before the War she had been doing part-time research work in the Cancer Research Laboratories of the Middlesex Hospital, and when the military hospital closed she accepted full-time work there under the Medical Research Council.

Only the comparatively few people who came into intimate touch with Dr. Chambers realised her full value. Her wide experience of general pathology and extraordinary ability to concentrate entirely on the matter in hand made her invaluable for research work. It was mainly due to her foresight and inspiration that the Marie Curie Hospital at Hampstead came into being. She realised that for satisfactory radium treatment it was essential to have the close co-operation of surgeon, physicist and pathologist, and the excellent results of treatment of uterine cancer at that hospital show to what an extent she succeeded in securing this collaboration.

Dr. Chambers contributed many papers to the scientific press on the effects of radiation on malignant and normal cells. The fact that animals, after the absorption of malignant tumours which had been very accurately irradiated, were often immune to tumour growth was always at the back of her mind for its possible clinical application. So recently as last winter she spent several months in Paris, where she carefully studied the X-ray treatment of cancer of the breast by Prof. Coutard, whose methods she felt gave more hope of attaining this desired effect than any other treatment of the disease in use at the present time.

\section{Mr. J. H. Ronaldson}

James Henry Ronaldson, who died on August 5, was a very well-known and much respected consulting mining engineer and geologist. He was born in the county of East Lothian and received his scientific and technical education at the Universities of Edinburgh and Liège. He travelled widely, but was probably best known in Australia and South Africa, where he had resided for comparatively long periods. He made London his headquarters as from 1910, and his business, until the outbreak of the Great War, took him to all sorts of countries. Shortly after the outbreak of the War, he found himself in the Ministry of Munitions, but after a short period of service there, Messrs. Brotherton and Co., Leeds, who had gone in for the manufacture of munitions, applied for his services, and he supervised their manufacture of explosives until 1918. After that he continued his practise, and for a few years was associated with Dr. William Cullen in consulting business.

Ronaldson was not only an excellent mining engineer but also a very good geologist, and it was this happy combination which made his reports so valuable to those who employed him. Moreover, he was the soul of integrity, and he never allowed 